\title{
OPTIMALISASI WAKTU PENYELESAIAN PEKERJAAN PROYEK KONSULTAN PENGAWASAN PADA DINAS PEKERJAAN UMUM DI KOTA TARAKAN
}

\section{Optimization of Completion Time Job In Monitoring Project Consultants In The City Department Of Public Works of Tarakan}

\author{
Achmad Syaihu ${ }^{1}$, M. Ruslin Anwar ${ }^{2}$, Alwafi Pujiraharjo ${ }^{3}$ \\ 1,2,3 Jurusan Teknik Sipil Program Magister, Fakultas Teknik, Universitas Brawijaya Malang \\ Jl. MT. Haryono No. 167 Malang, 65145, Jawa Timur \\ E-mail: bay_teguh@yahoo.com
}

\begin{abstract}
The research aimed at knowing the optimal time of the project work and supervision. Project in general has deadline, it means project should be completed before or exactly at the determined time. Beside that the delay has consequences of the loss of other supervision works, while for the owner, the delay in the project completion will cause the bad notes, so the use of project development yield will be delayed. With PERT and CPM method able to determine the network planning in a project stage by stage in series to complete the project. With time schedule able to arrange network planning and determine the back and forth of the and the sag time. The analysis of the implementation and supervision that is taken from three field of irrigation, highways, and urban planning consist of 120 days of calendar, 150 days of calendar, and 360 days of calendar. It can be optimized to be 91 days of calendar, 118 days of calendar and 280 days of calendar and the irrigation, highways and urban planning of supervision able to complete 104 days of calendar, 134 and 300 days of calendar, the conclusion of the research, the three time optimal fields able to complete the work, the $Z=(99.99 \%, 98.98 \%$, and $99.99 \%)$ and supervision able to complete in the field the project work exactly at the determined time (95.91\%, 93.94\% and $99.99 \%)$.
\end{abstract}

Keywords: time optimization, PERT, and CPM

\begin{abstract}
Abstrak
Penelitian yang dilakukan ini bertujuan untuk mengetahui waktu optimal pekerjaan proyek dan pengawasan. Proyek pada umumnya memiliki batas waktu (deadline), artinya proyek harus diselesaikan sebelum atau tepat pada waktu yang telah ditentukan. Selain itu adanya keterlambatan berakibat kehilangan peluang pekerjaan pengawasan lain. adapun bagi owner keterlambatan penyelesaian pekerjaan proyek akan menyebabkan catatan yang tidak baik, sehingga penggunaan hasil pembangunan proyek menjadi mundur atau terlambat. Dengan metode PERT dan CPM dapat menentukan lintasan kritis (network planning) dalam suatu kegiatan proyek tahap demi tahap secara berurutan untuk penyelesaian kegiatan proyek tersebut.Dengan time schedule dapat menyusun network planning dan menentukan hitungan maju mundur dan kelongaran waktu.Hasil analisa pelaksanan dan pengawasan yang diambil tiga bidang PSDA,Bina Marga dan Cipta Karya terdiri dari 120 hari kalender, 150 hari kalender dan 360 hari kalender. Dapat optimalisasi waktu fisik menjadi 91 hari kalender menjadi 118 dan menjadi 280 hari kalender dan Bidang PSDA, Bina Marga dan Cipta Karya pengawasan dapat menyelesaikan 104 hari kalender, 134 dan 300 hari kalender,kesimpulan dari penelitian ini ketiga bidang Optimal waktu dapat menyelesaikan pekerjaan,nilai $\mathrm{Z}=(99.99 \%, 98.98 \%$, and $99.99 \%)$ dan pengawasan dapat meyelasaikan dilapangan kegiatan proyek tepat pada waktu yang telah ditentukan $(95,91 \%$, 93,94\%, 99,99\%).
\end{abstract}

Kata kunci : Optimalisasi Waktu.PERT dan CPM

\section{PENDAHULUAN}

Proyek pada umumnya memiliki batas waktu (deadline), artinya proyek harus diselesaikan sebelum atau tepat pada waktu yang telah ditentukan. Berkaitan dengan masalah proyek ini maka keberhasilan pelaksanaan sebuah proyek tepat pada waktunya merupakan tujuan yang penting baik bagi pemilik proyek 
maupun, konsultan pengawas, serta kontraktor.Demi kelancaran jalannya sebuah proyek dibutuhkan manajemen yang akan mengelola proyek dari awal hingga proyek berakhir, yakni manajemen proyek. Manajemen proyek mempunyai sifat istimewa,dimana waktu kerja manajemen dibatasi oleh jadwal yang telah ditentukan. Perubahan kondisi yang begitu cepat menuntut setiap pimpinan yang terlibat dalam proyek untuk dapat mengantisipasi keadaan,perusahaan-perusahaan yang bergerak di bidang konsultan masih sangat kurang daerah di Kalimantan Utara, dengan demikian untuk membantu kelancaran pada pelaksanaan pekerjaan pengawasan di lapangan. Untuk pekerjaan fisik yang selalu mendapat kendala, baik kendala yang sudah diperhitungkan, maupun yang di luar perhitungan pengawasan.Kendala ini menjadi penyebab terhambatnya pekerjaan proyek, sehingga pekerjaan proyek tersebut tidak berlangsung sesuai dengan rencana. Oleh karena itu dalam pengawasan harus mengetahui apa yang akan terjadi pada suatu pekerjaan itu terhambat yang harus dilakukan oleh konsultan dan pengawasan kemungkinan waktu yang dibutuhkan untuk menyelesaikan proyek akan melebihi waktu yang telah ditentukan dalam dokumen kontrak pekerjaan. Bermacam-macam masalah penyebab keterlambatan pelaksanaan kegiatan proyek, masalah manajemen yang kurang baik keterlambatan pekerjaan konstruksi akan menyebabkan kerugian baik moril maupun materiel. Pihak yang terkena dampak kerugian tersebut adalah pihak yang berhubungan langsung dengan proyek yaitu konsultan pengawasan. Konsultan pengawasan akan mengalami kerugian waktu dan biaya, karena keuntungan yang harus diharapkan oleh konsultan berkurang, dan tidak mencapai target yang diharapkan bahkan tidak mendapatkan keuntungan sama sekali. Selain itu adanya keterlambatan berakibat kehilangan peluang pekerjaan perencanaan dan pengawasan lain. adapun bagi owner keterlambatan penyelesaian pekerjaan proyek akan menyebabkan catatan yang tidak baik, sehingga penggunaan hasil pembangunan proyek menjadi mundur atau terlambat. Konsultan yang menangani pekerjaan itu dengan tepat waktu, tentulah akan menguntungkan kedua belah pihak. Cara lain mengawasi pelaksanaan proyek yaitu diserahkan sepenuhnya pada orang yang melaksanakan proyek tersebut. Tetapi cara ini memerlukan berbagai persyaratan seperti misalnya pimpinan proyek harus dapat mengenali penyimpangan sedini mungkin dan melaporkannya pada yang berkepentingan serta dapat mengambil tindakan penyelamatan secara mandiri. Cara ini mungkin terlalu bebas dan jarang dipraktikan apalagi di negara sedang berkembang di mana tenaga ahli dan terampil sangat langka. (Sukanto, 2001). Pengawasan bisa dilakukan dengan menggunakan berita lisan, berita bentuk laporan tertulis ataupun melalui pandangan matanya sendiri. Seorang pengawas selalu mengadakan check dan recheck, review, evaluasi kemajuan pekerjaan, dan membandingkan terhadap tolak ukur yang ada, misalnya terhadap gambar kerja dan rencana kerja syarat (RKS) dan lain sebagainya. Sebelum seseorang pengawas memutuskan untuk menerima suatu hasil pekerjaan, diperlukan suatu standar ukuran yang dapat dijadikan pedoman. Langkahlangkah penting dalam pekerjaan pengawasan proyek: menetapkan tolak ukur yang akan digunakan; mengukur prestasi kerja; membandingkannya dengan prestasi yang seharusnya atau tolak ukur yang ada; menanggulangi terhadap prestasi yang kurang cukup atau tidak memenuhi persyaratan (Paulu, $d k k, 1986)$. Metode Jalur Kritis (Critical Path Method - CPM), yakni metode untuk merencanakan dan mengawasi proyek-proyek merupakan sistem yang paling banyak dipergunakan diantara semua sistem lain yang memakai prinsip pembentukan jaringan. CPM merupakan analisa jaringan kerja yang berusaha mengoptimalkan biaya total proyek melalui pengurangan atau percepatan waktu penyelesaian total proyek yang bersangkutan.. Heizer dan Render (2005) menjelaskan bahwa dalam dalam melakukan analisis jalur kritis, digunakan dua proses two-pass, terdiri atas forward pass dan backward pass. Dalam metode CPM dikenal dengan adanya jalur kritis, yaitu jalur yang memiliki rangkaian komponen-komponen kegiatan dengan total jumlah waktu terlama. dalam PERT digunakan distribusi peluang berdasarkan 
tiga perkiraan waktu untuk setiap kegiatan, antara lain waktu optimis, waktu pesimis, dan waktu realistis.

Jalur kritis terdiri dari rangkaian kegiatan kritis, dimulai dari kegiatan pertama sampai pada kegiatan terakhir proyek (Soeharto, 1995). Lintasan kritis (Critical Path) melalui aktivitas-aktivitas yang jumlah waktu pelaksanaannya paling lama. Jadi, lintasan kritis adalah lintasan yang paling menentukan waktu penyelesaian proyek secara keseluruhan. CPM memperkirakan waktu komponen kegiatan proyek dengan pendekatan deterministik satu angka yang mencerminkan adanya kepastian, maka PERT direkayasa untuk menghadapi situasi dengan kadar ketidak pastian (uncertainty) yang tinggi pada aspek kurun waktu kegiatan (Soeharto, 1999). Salah satu cara untuk mempercepat durasi proyek. Metode atau teknik analisis yang digunakan dalam penelitian ini adalah dengan menggunakan pendekatan Kurva "S", PERT dan CPM. prinsip penyusunan jaringan kerja pada metode PERT dan CPM adalah sama, namun terdapat perbedaan mendasar antara keduanya, yaitu

Tujuan dari penelitian yang dilakukan membentuk jaringan kerja atau (network planning) proyek pengawasan dan pelaksanaan dan waktu optimal satu kegiatan proyek pengawasan dan pelaksanaan di Kota Tarakan. data yang diperoleh dari lapangan dengan kontrak, langsung kepada konsultan dan pengawas pada Dinas Pekerjaan Umum Kota Tarakan yang terdiri dari Bidang Cipta Karya, Bidang Bina Marga dan Bidang Pengairan (PSDA).

\section{METODE PENELITIAN}

Berdasarkan cara menganalisis data dan jenis data, Sedangkan Penelitian kuantitatif adalah suatu pendekatan penelitian yang bersifat objektif, mencakup pengumpulan data dan analisis data kuantitatif. data yang diperoleh dari lapangan dengan kontrak kerja kepada konsultan dan pengawas pada Dinas Pekerjaan Umum dan Tata Ruang Kota Tarakan yang terdiri dari Bidang Cipta Karya, Bidang Bina Marga dan Bidang PSDA.
Data Primer : Yaitu data yang diperoleh dari lapangan dengan langsung kepada konsultan dan pengawas pada Dinas Pekerjaan Umum Kota Tarakan yang terdiri dari Bidang Cipta Karya, Bidang Bina Marga dan Bidang PSDA. Adapun data primer yang dibutuhkan adalah Schedule (Jadwal) pelaksanaan proyek dan rencana anggaran biaya (RAB) proyek yang sudah dilaksanakan oleh konsultan pengawasan dan kontraktor.

Data Sekunder : Data sekunder adalah data yang diperoleh dari literaturliteratur yang berhubungan dengan penelitian penulis, literatur ini perupa buku, jurnal yang berhubungan dengan penelitian penulis. penyusunan jaringan kerja pada metode PERT dan CPM adalah sama.Langkah - langkah dalam jaringan kerja untuk dua metodedalam menyusun jaringan kerja adalah sebagai berikut :

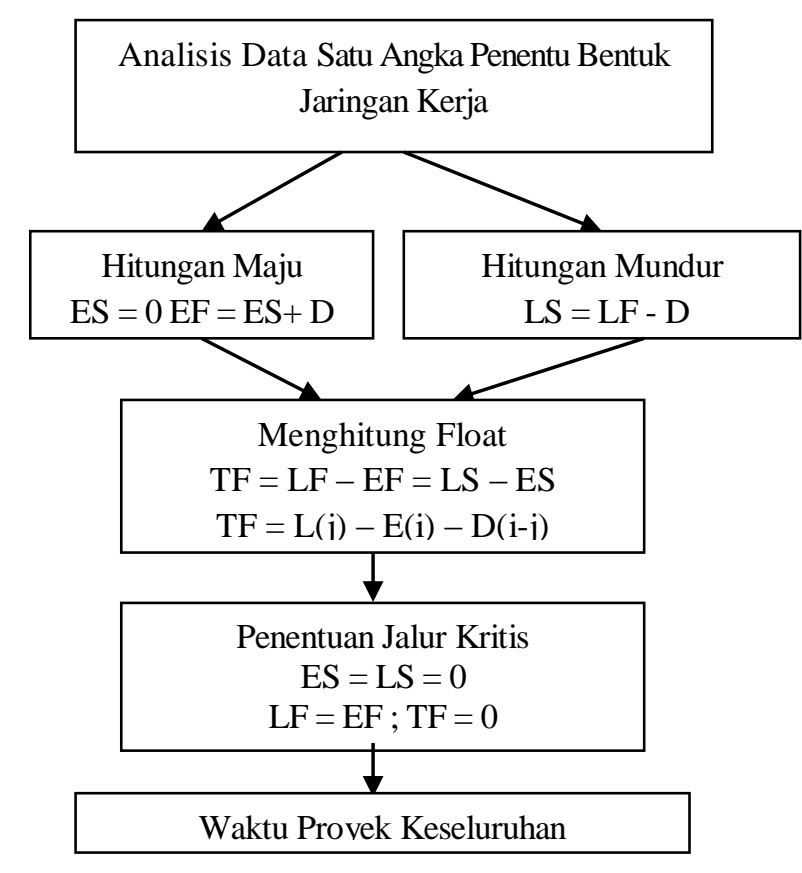

Gambar 1. Flow Chart CPM

\section{keterangan :}

ES $($ Earliest Start Time $)=$ waktu mulai paling awal suatu kegiatan.

EF (Earliest Finish Time) $=$ waktu selesai paling awal suatu kegiatan.

LS (Latest Allowable Start Time) $=$ waktu paling akhir kegiatan boleh dimulai.

LF (Latest Allowable Finish Time) = waktu paling akhir kegiatan boleh selesai.

$\mathrm{D}=\mathrm{D}(\mathrm{i}-\mathrm{j})=$ kurun waktu suatu kegiatan .

$\mathrm{L}(\mathrm{j})=$ waktu paling awal peristiwa dapat teijadi.

$\mathrm{E}(\mathrm{i})=$ waktu paling akhir peristiwa boleh terjadi.

$($ LF-EF $=0)$ atau $($ ES-LS $=0)=$ jalur kritis (kegiatan yang tidak dapat ditunda). 


\section{Penjelasan :}

Dalarn menentukan jalur kritis dipakai beberapa cara. Pertama adalah hitungan maju yang digunakan untuk menghitung ES (Earliest Start Time) awal mulai suatu kegiatan dan untuk menghitung EF (early finish), awal selesai suatu kegiatan. Kedua adalah hitungan mundur yang Digunakan untuk mengetahui waktu paling akhir memulai dan mengakhiri masing-masing kegiatan tanpa mempengaruhi penyelesaian proyek keseluruhan dari hasil perhitungan maju.Setelah didapat hitungan maju dan hitungan mundur maka dapat dihitung float/penundaan yang digunakan untuk mengetahui jumlah waktu yang diperbolehkan untuk menunda suatu kegiatan sehingga diketahui lintasan kritisnya (kegiatan yang tidak dapat ditunda pekerjaannya) apabila nilai $(\mathrm{LF}-\mathrm{EF}=0)$ atau (ES-LS=0) sehingga dapat diketahui waktu penyelesaian proyek bidang kepuan dan konsultan pengawasan di kota Tarakan, data keseluruhan yang diperlukan.

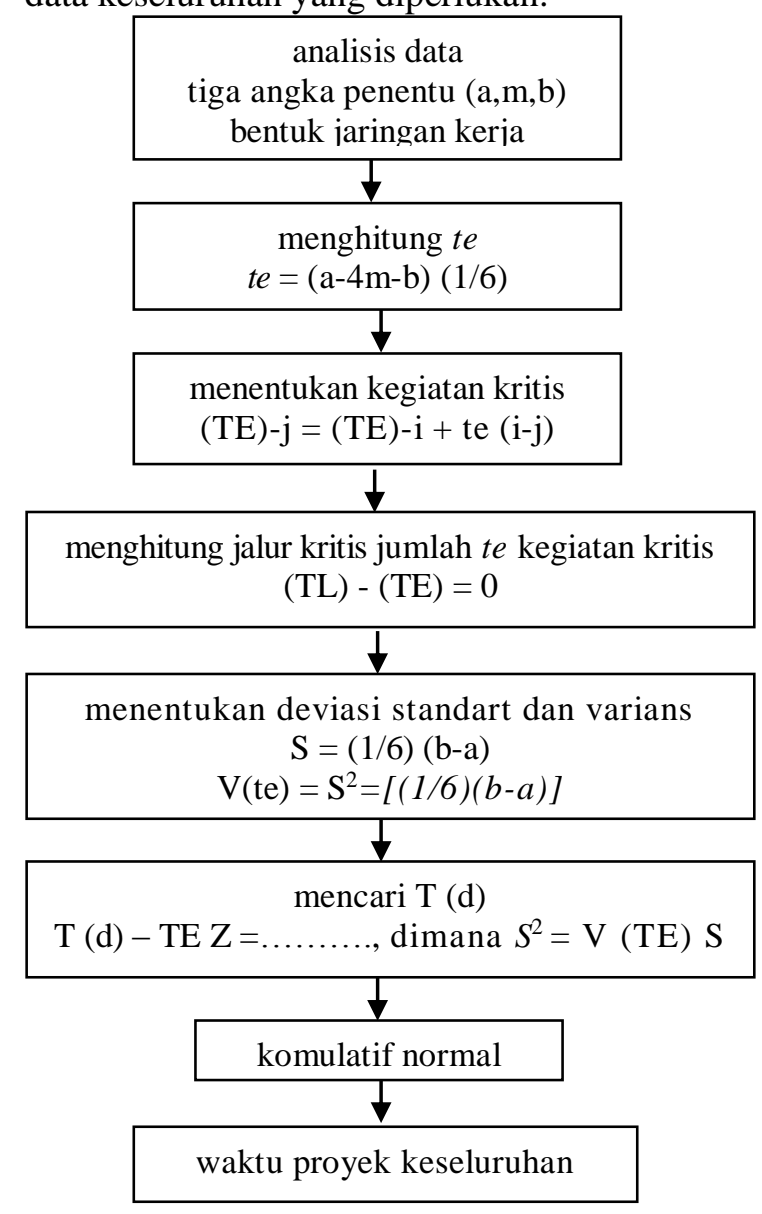

Gambar 2. Penyusunan Jaringan Kerja
Sumber : Imam Suharto, Hal. 240, 1991

te $($ Expected Duration Time $)=$ kurun waktu yang diharapkan.

$\mathrm{a}=$ waktu optimistik. $\mathrm{b}=$ waktu pesimistik. $\mathrm{m}=$ waktu paling mungkin.

$\mathrm{TE}(\mathrm{j})=$ peristiwa paling awal dapat selesai. $\mathrm{TE}(\mathrm{i})=$ peristiwa paling awal dapat dimulai.

$\mathrm{TL}(\mathrm{j})=$ peristiwa paling akhir dapat selesai. TL(i) = peristiwa paling akhir dapat dimulai.

$\mathrm{TE}=$ waktu paling awal peristiwa terjadi $=$ jumlah $t e$ kegiatan kritis.

$t e(i-j)=$ kurun waktu yang diharapkan dari kegiatan awal/sebelumnya ke kegiatan berikutnya.

$(\mathrm{TL}=\mathrm{TE}=0)=$ jalur kritis (kegiatan yang tidak dapat ditunda pekerjaannya).

$\mathrm{S}=$ deviasi standar kegiatan. $V(t e)=$ varians kegiatan. $\mathrm{V}(\mathrm{TE})=$ varians peristiwa.

$\mathrm{z}=$ angka kemungkinan mencapai target. $\mathrm{T}(\mathrm{d})=$ target jadwal.

\section{Penjelasan :}

Membuat jaringan kerja yang digunakan untuk menentukan tiga angka estimasi yaitu a (waktu optimistik), b (waktu pesimistik) dan $\mathrm{m}$ (waktu paling mungkin). Setelah ditentukan tiga angka estimasi tersebut maka bisa dihitung te (waktu yang diharapkan) sehingga dapat dihitung TE,TL, dan Slack yang digunakan untuk mengetahui lintasan kritisnya (kegiatan yang tidak dapat ditunda pekerjaannya) yaitu apabila nilai $\mathrm{TL}-\mathrm{TE}=0$. Setelah jalur kritis (kegiatan yang tidak dapat ditunda pekerjaannya) diketahui maka langkah berikutnya adalah menghitung deviasi standar dan varians kegiatan serta mencari $\mathrm{T}(\mathrm{d})$ yaitu target jadwal yang digunakan untuk menandai derajad ketidakpastian dalam estimasi kurun waktu sehingga target prosentasi proyek bidang kepuan dan konsulan pengawasan di kota tarakan dapat diketahui dengan melihat tabel kumulatif normal yang digunakan untuk mengetahui te (Expected Duration Time) kurun waktu yang diharapkan. adalah menghitung deviasi standar dan varians kegiatan serta mencari $\mathrm{T}(\mathrm{d})$ yaitu target jadwal yang digunakan untuk menandai derajad ketidakpastian dalam estimasi kurun waktu sehingga target prosentasi proyek bidang kepuan dan konsulan pengawasan di kota tarakan dapat diketahui dengan melihat tabel kumulatif normal yang digunakan untuk mengetahui. 


\section{HASIL DAN PEMBAHASAN}

Penelitian data ini diambil dari proyek Dinas Pekerjaan Umum dan Tata Ruang Kota Tarakan yang terbagi tiga bidang yaitu: Bidang PSDA, Bidang Bina Marga dan Cipta Karya di lingkup Dinas Pekerjaan Umum dan Tata Ruang Kota Tarakan di Provinsi Kalimantan Utara. Dari tiga bidang tersebut diambil tiga proyek peleksanan dan pengawasan pada masingmasing, yaitu bidang PSDA, Bina Marga, Cipta karya.

\section{a. PSDA}

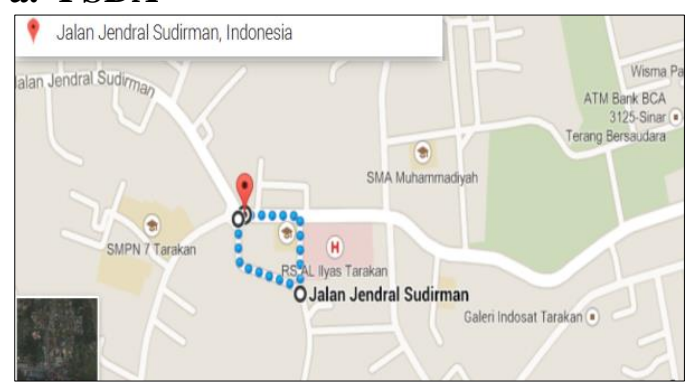

Gambar 3. Lokasi Pembangunan Saluran Drainase

Kegiata Pembangunan Saluran Drainase Jl. Anggrek dan Jl. RE. Martadinata Kota Tarakan

\section{Lokasi Kegiatan : Kota Tarakan}

Pemilik Proyek : Dinas Pekerjaan Umum dan Tata Ruang Kota Tarakan

Anggaran Kontraktor : Rp. 1.396.000.000.

Konsultan Pelaksanaa :PT.CMA/PT,MB : CV.MK, : 120 Hari Kalender

\section{b. Bidang Bina Marga}

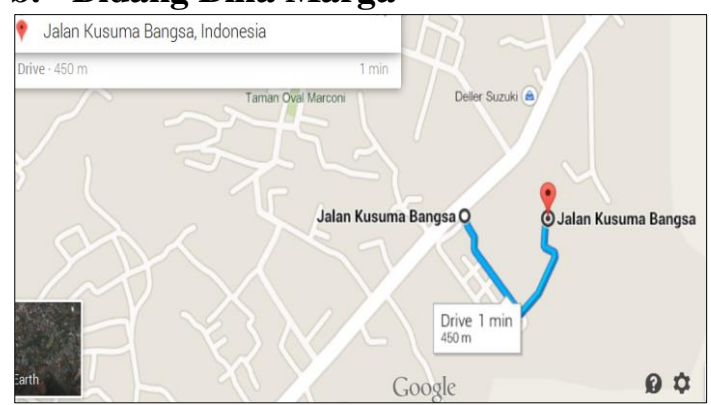

Gambar 4. Lokasi proyek pembangunan akses jalan menuju rusunawa pasar bompanjang
Nama Proyek Pembangunan/Peningkatan Jalan dan Jembatan Kota Tarakan

$\begin{array}{llr}\text { Lokasi Kegiatan } & \text { : Kota Tarakan, } \\ \text { Anggaran } & : \text { Rp. } 1.876 .235 .000 \\ \text { Pemilik Proyek } & \text { : Dinas Pekerjaan } \\ & \text { Umum dan Tata } \\ & \text { Ruang } & \text { Kota } \\ & \text { Tarakan } & \\ \text { Kontraktor } & : \text { PT. } & \text { TNM, } \\ \text { Konsultan } & : \text { CV.SAK } & \\ \text { Pelaksanaan } & : \text { 150 Hari Kalender }\end{array}$

\section{c. Bidang Cipta Karya}

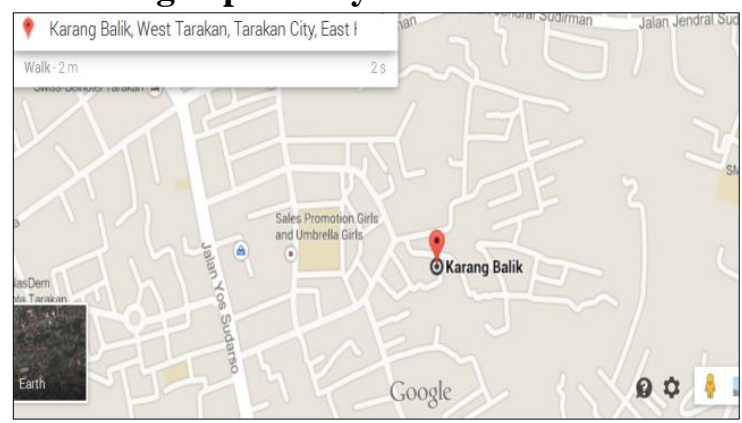

Gambar 5. Lokasi Proyek Pembangunan Gedung Kantor

\begin{tabular}{llr} 
Nama Proyek & \multicolumn{2}{l}{ : Pembangunan } \\
& Gedung Kantor \\
& Kota Tarakan \\
Lokasi Kegiatan & : Kota & Tarakan, \\
Anggaran & : Rp. 1.417 .830 .000 \\
Pemilik Proyek & : Dinas Pekerjaan \\
& Umum dan Tata \\
& Ruang & Kota \\
& Tarakan & \\
Kontraktor & $:$ PT. & CPE, \\
Konsultan & : CV. BCK & \\
Pelaksanaan & : 360 Hari Kalender
\end{tabular}

Perhitungan Analisa Jaring Kerja Critical Path Method ( Untuk Pekerjaan Pembangunan Saluran Drainase ) hasil penelitian diketahui bahwa pembangunan saluran drainase/goronggorong tersebut melibatkan pengawasan untuk mempermudah kegiatan dilapangan. Untuk mempermudah masing-masing aktivitas disusun daftar rencana kegiatan serta disusun network planning. Hal ini dilakukan untuk optimasi waktu pelaksanaan proyek pembangunan saluran drainase. Analisis optimasi waktu berdasarkan data time schedule.Metode 
PERT dan CPM didapat Lintasan kritis. Dari perhitungan dengan mengunakan metode PER-CPM dapatlah waktu optimal 91 hari kalender dan 13 minggu,lebih cepat dari kontrak 120 hari kalender. Konsultan pengawasan waktu optimal yang didapat yaitu 104 hari kalender ini sudah termasuk dengan laporan keowner (pemilik Proyek ).

Tabel 1. Urutan dan volume pekerjaan pembangunan gedung kantor kota tarakan

\begin{tabular}{|c|c|c|c|c|}
\hline N0 & Uraian Pekerjaan & Hari & Volume & Pelaksanaan dilapangan \\
\hline$\overline{\mathrm{A}}$ & $\begin{array}{l}\text { Pengukuran,Pasang ptk } \\
\text { penuntun }\end{array}$ & 1 Minggu & $3 \mathrm{Ls}$ & Pengukuran,Pasang ptk penuntun \\
\hline B & Pekerjaan Galian A dan B & 3 Minggu & $1514 \mathrm{M} 3$ & Galian A dan B \\
\hline $\mathrm{C}$ & $\begin{array}{l}\text { Pekerjaan Pancangan Kayu } \\
\text { Ulin }\end{array}$ & 2 Minggu & $440 \mathrm{Btg}$ & Pancangan \\
\hline $\mathrm{D}$ & $\begin{array}{l}\text { Pasangan Batu Gunung/Belah } \\
\text { Pembesian,Cor,Pipa,PVC, } \\
\text { Plesteran }\end{array}$ & 6 Minggu & $\begin{array}{c}501,51 \mathrm{~m} 3 \\
16988,23 \mathrm{~kg} \\
183,96 \mathrm{~m} 3 \\
59 \mathrm{Btg}, \\
823,44 \mathrm{~m} 2\end{array}$ & Kerja Bersamaan \\
\hline
\end{tabular}

Tabel 2. Durasi waktu dan predecessor pembangunan gedung kantor kota tarakan

\begin{tabular}{clcc}
\hline No & \multicolumn{1}{c}{ Uraian Pekerjaan } & Durasi & Predeceessor \\
Aktivitas & \multicolumn{1}{c}{ Start } & & \\
\hline & & 3 & 0 \\
A & Pengukuran & 3 & 0 \\
B & Pasang Patok Pembantu dll & 7 & 0 \\
C & Galian Tanah Biasa & 10 & 0 \\
D & Penulangan Besi Beton Polos & 7 & 0 \\
E & Cor Lantai Beton & 7 & E \\
F & Galian Tanah Biasa & 10 & F \\
G & Pancang Kayu Ulin & 41 & G \\
H & Pasangan Batu Gunung dengan Mortar & 10 & G \\
I & Penulangan Besi Beton Polos & 7 & G \\
J & Cor Lantai Beton & 10 & I \\
K & Plesteran & 10 & J,L,H \\
L & Pipa PVC & 61 & \\
\end{tabular}

Tabel 3. Perhitungan Estimasi Waktu ET, LT pembangunan gedung kantor kota tarakan

\begin{tabular}{cccccc}
\hline Optimis & $\begin{array}{c}\text { Estimasi Waktu (Hari) } \\
\text { Paling Mungkin }\end{array}$ & Pisimis & $\mathrm{Te}=(\mathrm{a}+4 \mathrm{~m}+\mathrm{b}) / 6$ & $\mathrm{~S}=(\mathrm{b}-\mathrm{a}) / 6$ & $\mathrm{Vte}=\mathrm{S} 2$ \\
\hline$(\mathrm{a})$ & $(\mathrm{m})$ & $(\mathrm{b})$ & 3 & 0,50 & 1,0 \\
2 & 3 & 5 & 3 & 0,50 & 1,0 \\
2 & 3 & 9 & 7 & 0,67 & 1,3 \\
5 & 7 & 15 & 10 & 1,67 & 3,3 \\
5 & 10 & 9 & 7 & 0,67 & 1,3 \\
5 & 7 & 9 & 7 & 0,67 & 1,3 \\
5 & 7 & 15 & 10 & 1,67 & 3,3 \\
5 & 10 & 44 & 41 & 0,83 & 1,7 \\
39 & 41 & 15 & 10 & 1,67 & 3,3 \\
5 & 10 & 9 & 7 & 0,67 & 1,3 \\
5 & 7 & 15 & 10 & 1,67 & 3,3 \\
5 & 10 & 15 & 10 & 1,67 & 3,3 \\
5 & 10 & 62 & 61 & 0,50 & 1,0 \\
59 & 61 & & & & \\
\hline
\end{tabular}

ET dan LT menunjukan waktu yang dibutuhkan untuk memulai dan menyelesaikan aktivitas, misalnya A bernilai nol karena A baru mulai aktivitas,
B bernilai 1 karena B telah melakukan aktivitas yaitu aktivitas pendahuluan dan seterusnya. Akhir aktivitas menunjukan lamanya waktu penyelesaian dalam proyek 
tersebut, yaitu ditunjukan 13 minggu dengan nilai 91 hari yang nilai ET sama dengan LT. Pelaksanaan pengawasan proyek pembangun Saluran Drainase Kota Tarakan selesai pada waktu 14 minggu atau 104 hari kalender, diketahui dari nilai akhir ET dan LT.waktu Lintasan kritis pengawasan pembangunan Saluran Drainase kota tarakan adalah sebagai berikut :Biaya Kantor,Biaya Tansportasi, Biaya Tenaga Teknik

\section{Perhitungan Analisa Jaringan Kerjauntuk Pekerjaan Pembangunan/ Peningkatan Jalan dan Jembatan Kota Tarakan}

Berdasarkan data yang ada, dari hasil penelitian diketahui bahwa
Jembatan Kota Tarakan tersebut melibatkan pengawasan untuk mempermudah kegiatan dilapangan.Untuk mempermudah masingmasing aktivitas disusun daftar rencana kegiatan serta disusun network planning. Hal ini dilakukan untuk optimasi waktu pelaksanaan proyek pembangunan jalan dan jembatan kota tarakan. Analisis optimasi waktu berdasarkan data time schedule.Metode PERT dan CPM didapat.Dari perhitungan dengan mengunakan metode PERT-CPM dapatlah waktu optimal 118 hari kalender dan 17 minggu, lebih cepat dari kontrak 150 hari kalender. Konsultan pengawasan waktu optimal yang didapat yaitu 134 hari kalender ini sudah termasuk dengan lapora keowner ( pemilik Proyek ).

Tabel 4. Urutan pekerjaan pembangunan peningkatan jalan dan jembatan kota tarakan

\begin{tabular}{|c|c|c|c|c|}
\hline \multirow{3}{*}{ A } & Pekerjaan & Durasi & Keterangan & \\
\hline & $\begin{array}{l}\text { Pekerjaan } \\
\text { Pendahuluan }\end{array}$ & & $137,61 \mathrm{~m} 3$ & \\
\hline & Pekerjaan Box Culvet & 14 Minggu & $\begin{array}{l}62 \text { Tik, } \\
70,11 \mathrm{M} 2\end{array}$ & Kerja Bersaman \\
\hline B & $\begin{array}{l}\text { Pekerjaan Daiuker, } \\
\text { Urungan Tanah, } \\
\text { Badan Jalan }\end{array}$ & 7 Minggu & $\begin{array}{l}1 \mathrm{Ls}, 1812 \mathrm{~m} 2 \\
3139,50 \mathrm{Ltr} \text { aspal }\end{array}$ & Kerja Bersaman \\
\hline
\end{tabular}

Tabel 5. Durasi dan prodecessor pembangunan peningkatan jalan dan jembatan kota tarakan

\begin{tabular}{|c|c|c|c|}
\hline \\
\hline $\begin{array}{c}\text { No } \\
\text { Aktivitas }\end{array}$ & Uraian Pekerjaan & Durasi & Predeceessor \\
\hline & START & & \\
\hline A & Mobilisasi & 7 & 0 \\
\hline B & Penyiapan Badan Jalan & 5 & A \\
\hline $\mathrm{C}$ & Urugan Tanah Badan Jalan & 5 & B \\
\hline $\mathrm{D}$ & Lapisan Pondasi Agregat Kls B & 5 & $\mathrm{C}$ \\
\hline E & Lapisan Pondasi Agregat Kls A & 5 & $\mathrm{C}$ \\
\hline $\mathrm{F}$ & Alat-alat berat Pekerjaan Memadatkan Badan Jalan & 7 & $\mathrm{D}$ \\
\hline G & Lapisan Pengikat (Prime Coat) & 5 & $\mathrm{E}$ \\
\hline $\mathrm{H}$ & Asphalt Base Trested (ATB) & 5 & $\mathrm{~F}, \mathrm{G}$ \\
\hline I & Box Culvert & 13 & $\mathrm{H}$ \\
\hline $\mathrm{J}$ & Persiapan/Finising Untuk Pengaspalan & 13 & I \\
\hline $\mathrm{K}$ & Pembuatan Duicker & 24 & $\mathrm{H}$ \\
\hline $\mathrm{L}$ & Persiapan/Finising Untuk Pengaspalan & 24 & $\mathrm{~K}$ \\
\hline M & Mobilisasi & 7 & $\mathrm{~J}, \mathrm{~L}$ \\
\hline $\mathrm{N}$ & Penyiapan Badan Jalan & 5 & $\mathrm{M}$ \\
\hline $\mathrm{O}$ & Urugan Tanah Badan Jalan & 5 & $\mathrm{~N}$ \\
\hline $\mathrm{P}$ & Lapisan Pondasi Agregat Kls B & 5 & $\mathrm{O}$ \\
\hline Q & Lapisan Pondasi Agregat Kls A & 5 & $\mathrm{P}$ \\
\hline $\mathrm{R}$ & Alat-alat berat Pekerjaan & 7 & $\mathrm{Q}$ \\
\hline $\mathrm{S}$ & Memadatkan Badan Jalan & 5 & $\mathrm{R}$ \\
\hline $\mathrm{T}$ & Lapisan Pengikat (Prime Coat) & 5 & $\mathrm{~S}$ \\
\hline $\mathrm{U}$ & Asphalt Base Trested (ATB) & 5 & $\mathrm{~T}$ \\
\hline & END & & \\
\hline
\end{tabular}


Tabel 6. Perhitungan Estimasi waktu pembangunan peningkatan jalan dan jembatan kota tarakan

\begin{tabular}{cccccc}
\hline $\begin{array}{c}\text { Optimis } \\
\text { (a) }\end{array}$ & $\begin{array}{c}\text { Estimasi Waktu (Hari) } \\
\text { Paling Mungkin } \\
(\mathrm{m})\end{array}$ & $\begin{array}{c}\text { Pisimis } \\
(\mathrm{b})\end{array}$ & $\mathrm{Te}=(\mathrm{a}+4 \mathrm{~m}+\mathrm{b}) / 6$ & $\mathrm{~S}=(\mathrm{b}-\mathrm{a}) / 6$ & $\mathrm{Vte}=\mathrm{S} 2$ \\
\hline 5 & 7 & 9 & 7 & 0,67 & 1,33 \\
3 & 5 & 7 & 5 & 0,67 & 1,33 \\
3 & 5 & 7 & 5 & 0,67 & 1,33 \\
3 & 5 & 7 & 5 & 0,67 & 1,33 \\
3 & 5 & 7 & 5 & 0,67 & 1,33 \\
5 & 7 & 9 & 7 & 0,67 & 1,33 \\
3 & 5 & 7 & 5 & 0,67 & 1,33 \\
3 & 5 & 7 & 5 & 0,67 & 1,33 \\
10 & 13 & 16 & 13 & 1 & 2 \\
10 & 13 & 16 & 13 & 1 & 2 \\
20 & 24 & 28 & 24 & 1,33 & 2,67 \\
20 & 24 & 28 & 24 & 1,33 & 2,67 \\
5 & 7 & 9 & 7 & 0,67 & 1,33 \\
3 & 5 & 7 & 5 & 0,67 & 1,33 \\
3 & 5 & 7 & 5 & 0,67 & 1,33 \\
3 & 5 & 7 & 5 & 0,67 & 1,33 \\
3 & 5 & 7 & 5 & 0,67 & 1,33 \\
5 & 7 & 9 & 7 & 0,67 & 1,33 \\
3 & 5 & 7 & 7 & 0,67 & 1,33 \\
3 & 5 & 7 & 5 & 0,67 & 1,33 \\
3 & 5 & 7 & 5 & 0,67 & 1,33 \\
\hline
\end{tabular}

ET dan LT menunjukan waktu yang dibutuhkan untuk memulai dan menyelesaikan aktivitas, misalnya A bernilai nol karena A baru mulai aktivitas, B bernilai 1 karena B telah melakukan aktivitas yaitu aktivitas pendahuluan dan seterusnya. Akhir aktivitas menunjukan lamanya waktu penyelesaian dalam proyek tersebut, yaitu ditunjukan 17 minggu dengan nilai 118 hari yang nilai ET sama dengan LT. Pelaksanaan pengawasan proyek pembangun/ peningkatan jalan dan jembatan kota Tarakan selesai pada waktu 19 minggu atau 134 hari kalender, diketahui dari nilai akhir ET dan LT. waktu Lintasan kritis pengawsan pembangunan/ peningkatan jalan dan jembatan kota tarakan adalah sebagai berikut:Biaya kantor,Biaya Tansportasi,Biaya tenaga teknik

\section{Perhitungan Analisa Jaringan Kerja untuk Pekerjaan Pembangunan Gedung Kantor}

Berdasarkan data yang ada, dari hasil penelitian diketahui bahwa Pembangunan Gedung Kantor Kota Tarakan tersebut melibatkan pengawasan untuk mempermudah kegiatan dilapangan.Untuk mempermudah masingmasing aktivitas disusun daftar rencana kegiatan serta disusun network planning. Hal ini dilakukan untuk optimasi waktu pelaksanaan proyek pembangunan Gedung Kantor Kota Tarakan. Analisis optimasi waktu berdasarkan data time schedule.Metode PERT dan CPM didapat.Dari perhitungan dengan mengunakan metode PERT-CPM dapatlah waktu optimal 280 hari kalender dan 40 minggu,lebih cepat dari kontrak 360 hari kalender. Konsultan pengawasan waktu optimal yang didapat yaitu: 300 hari kalender ini sudah termasuk dengan laporankeowner (pemilik Proyek ). 
Tabel 7 Perhitungan Analisa Jaringan Kerja untuk Pekerjaan Pembangunan Gedung Kantor

\begin{tabular}{|c|c|c|c|c|}
\hline & Pekerjaan & Durasi & Keterangan & \\
\hline A & Pekerjaan Pendahuan & 2 Minggu & $3 \mathrm{Ls}, 295$ m2, 44 m' & Kerja Bersaman \\
\hline B & $\begin{array}{l}\text { Perkerjaan Timbunan } \\
\text { Galian }\end{array}$ & 14 Minggu & $295 \mathrm{~m} 3$ & Timbunan dan Galian \\
\hline $\mathrm{C}$ & Pekerjaan Pondasi & 2 Minggu & 504 Btg, 252 Titik & Pancangan Beton \\
\hline $\mathrm{D}$ & $\begin{array}{l}\text { Pekerjaan Beton } \\
\text { Lantai Idan Lantai II }\end{array}$ & 15 Minggu & $97,42 \mathrm{~m} 356,66$ & Kerja Bersamaan \\
\hline $\mathrm{E}$ & $\begin{array}{l}\text { Pekerjaan } \\
\text { PasangandanPlesteran } \\
\text { Lantai I/II }\end{array}$ & 8 Minggu & $\begin{array}{l}46,13 \mathrm{~m} 3,1243,39 \mathrm{~m} 2 \\
23,84 \mathrm{~m} 3,961,65 \mathrm{~m} 2\end{array}$ & Kerja Bersaman \\
\hline $\mathrm{F}$ & $\begin{array}{l}\text { Pekerjaan } \\
\text { Kusen,Pintu / Jendela } \\
\text { Lantai I /II }\end{array}$ & 6 Minggu & $\begin{array}{l}2,46 \mathrm{~m} 3,40,91 \mathrm{~m} 2,880 \\
\mathrm{~m}, 118 \mathrm{Bh}, 1,90 \mathrm{~m} 3,26,50 \\
\mathrm{~m}, 118 \mathrm{Bh}\end{array}$ & Kerja Bersaman \\
\hline G & Pengecetan Lantai I/II & 12 Minggu & 1154,91 m’, 958,42 m’ & Kerja Bersaman \\
\hline $\mathrm{H}$ & $\begin{array}{l}\text { Pekerjaan Paving } \\
\text { Block }\end{array}$ & & $\begin{array}{l}25,74 \mathrm{~m} 3,137,75 \mathrm{~m} 2,8,50 \\
\mathrm{~m}\end{array}$ & Kerja Bersaman \\
\hline
\end{tabular}

Tabel 8.Perhitungan Durasi untuk Pekerjaan Pembangunan Gedung Kantor

\begin{tabular}{|c|c|c|c|}
\hline $\begin{array}{c}\text { No } \\
\text { Aktivitas }\end{array}$ & Uraian Pekerjaan & Durasi & Predeceessor \\
\hline & START & & \\
\hline A & Pendahuluan & 5 & 0 \\
\hline B & Galian dan Timbunan & 14 & A \\
\hline $\mathrm{C}$ & Pondasi & 5 & B \\
\hline $\mathrm{D}$ & Bekisting dan Tulangan Kolom dan Sloof Lantai 1 & 5 & $\mathrm{C}$ \\
\hline $\mathrm{E}$ & Sanitasi Lantai 1 dan 2 & 6 & $\mathrm{D}$ \\
\hline $\mathrm{F}$ & Pekerjaan Beton Kolom dan Sloof Lantai 1 & 15 & $\mathrm{D}$ \\
\hline G & Bekisting dan Tulangan Balok dan Plat Lanati 2 & 15 & $\mathrm{D}$ \\
\hline $\mathrm{H}$ & Bekisting dan Tulangan Kolom Lanati 2 & 15 & G \\
\hline I & Pembongkaran Bekisting Lanati 1 & 6 & $\mathrm{~F}$ \\
\hline $\mathrm{J}$ & Pasangan Dinding dan Plesteran Lantai 1 dan 2 & 9 & I \\
\hline K & Pek.Kusen,Pintu Dan Jendela,Pengunci dll & 6 & $\mathrm{~J}$ \\
\hline $\mathrm{L}$ & Mekanikal dan Elekrikal Lantai 1 dan 2 & 9 & $\mathrm{G}$ \\
\hline M & Penulangan dan Beton Ringbalk & 15 & $\mathrm{H}$ \\
\hline $\mathrm{N}$ & Kuda - Kuda dan Rangka Atap & 10 & $\mathrm{M}$ \\
\hline $\mathrm{O}$ & Penutup Atap & 10 & $\mathrm{~N}$ \\
\hline $\mathrm{P}$ & Plafond Lantai 1 dan Lantai 2 & 6 & $\mathrm{O}$ \\
\hline $\mathrm{Q}$ & Pengecatan Lantai 1 dan Lantai 2 & 12 & $\mathrm{~J}$ \\
\hline $\mathrm{R}$ & Paving Blok dan Halaman & 10 & Q \\
\hline $\mathrm{S}$ & $\begin{array}{l}\text { Pembersihan/Finishing } \\
\text { END }\end{array}$ & 10 & $\mathrm{R}$ \\
\hline
\end{tabular}

Tabel 9. Perhitungan ET dan LT untuk Pekerjaan Pembangunan Gedung Kantor

\begin{tabular}{cccccc}
\hline $\begin{array}{c}\text { Optimis } \\
\text { (a) }\end{array}$ & $\begin{array}{c}\text { Paling Mungkin } \\
(\mathrm{m})\end{array}$ & $\begin{array}{c}\text { Pisimis } \\
(\mathrm{b})\end{array}$ & $\mathrm{Te}=(\mathrm{a}+4 \mathrm{~m}+\mathrm{b}) / 6$ & $\mathrm{~S}=(\mathrm{b}-\mathrm{a}) / 6$ & $\mathrm{Vte}=\mathrm{S} 2$ \\
\hline 3 & 5 & 7 & 5 & 0,67 & 1,33 \\
10 & 14 & 18 & 14 & 1,33 & 2,67 \\
3 & 5 & 7 & 5 & 0,67 & 1,33 \\
3 & 5 & 7 & 5 & 0,67 & 1,33 \\
4 & 6 & 8 & 6 & 0,67 & 1,33 \\
12 & 15 & 17 & 15 & 0,83 & 1,67 \\
12 & 15 & 17 & 15 & 0,83 & 1,67 \\
12 & 15 & 17 & 15 & 0,83 & 1,67 \\
4 & 6 & 8 & 6 & 0,67 & 1,33 \\
5 & 9 & 14 & 9 & 1,50 & 3,00 \\
\hline
\end{tabular}


Lanjutan Tabel 9. Perhitungan ET dan LT untuk Pekerjaan Pembangunan Gedung Kantor

\begin{tabular}{cccccc}
\hline $\begin{array}{c}\text { Optimis } \\
\text { (a) }\end{array}$ & $\begin{array}{c}\text { Paling Mungkin } \\
(\mathrm{m})\end{array}$ & $\begin{array}{c}\text { Pisimis } \\
\text { (b) }\end{array}$ & $\mathrm{Te}=(\mathrm{a}+4 \mathrm{~m}+\mathrm{b}) / 6$ & $\mathrm{~S}=(\mathrm{b}-\mathrm{a}) / 6$ & $\mathrm{Vte}=\mathrm{S} 2$ \\
\hline 4 & 6 & 8 & 6 & 0,67 & 1,33 \\
6 & 9 & 12 & 9 & 1,00 & 2,00 \\
12 & 15 & 17 & 15 & 0,83 & 1,67 \\
7 & 10 & 13 & 10 & 1,00 & 2,00 \\
7 & 10 & 13 & 10 & 1,00 & 2,00 \\
4 & 6 & 8 & 6 & 0,67 & 1,33 \\
8 & 12 & 16 & 12 & 1,33 & 2,67 \\
7 & 10 & 13 & 10 & 1,00 & 2,00 \\
7 & 10 & 13 & 10 & 1,00 & 2,00 \\
\hline
\end{tabular}

ET dan LT menunjukan waktu yang dibutuhkan untuk memulai dan menyelesaikan aktivitas, misalnya A bernilai nol karena A baru mulai aktivitas, B bernilai 1 karena $B$ telah melakukan aktivitas yaitu aktivitas pendahuluan dan seterusnya. Akhir aktivitas menunjukan lamanya waktu penyelesaian dalam proyek tersebut, yaitu ditunjukan 40 minggu dengan nilai 280 hari yang nilai ET sama dengan LT. Pelaksanaan pengawasan proyek pembangunan gedung kantor selesai pada waktu 43 minggu atau 300 hari kalender, diketahui dari nilai akhir ET dan LT. waktu Lintasan kritis pengawsan pembangunan Gedung Kantor kota tarakan adalah sebagai berikut : Biaya Kantor, Biaya Tansportasi, Biaya Tenaga Teknik

Pembangunan Saluran Drainase : Dari Hasil Jalur Keritis diambil : Pendahuluan, Galian Tanah A, Galian Tanah B, Pancang Kayu Ulin Didapat 91 hari Probabilitas $=99,83$ $\%=\mathrm{Z}=2,93 \mathrm{Td}=120$ hari. Pembangunan Jalan dan Jembatan : Dari Hasil Jalur Keritis diambil : Pendahuluan dan perkerjaan Pengaspalan. Didapat 118 hari Probabilitas $=\mathrm{Z}=2,66 \mathrm{Td}=150$ hari

Pembangunan Bangunan Kantor : Dari Hasil Jalur Keritis didapat: Pendahuluan, Pekerjaan Timbunan, Galian, dan Urugan, Pekerjaan Pondasi, Pekerjaan Beton, Pekerjaan Pasangan dan Plesteran, Pekerjaan Kusen, Pintu dan Jendela, Pekerjaan Pengecatan, Pekerjaan Paving Blok dan Halaman.Didapat 260 hari Probabilitas $=99,98 \%=\mathrm{Z}=3,50 \mathrm{Td}=$ 360 hari
Konsultan Pengawasan Saluran Drainase : Dari Hasil Jalur Keritis diambil: Tenaga Teknik, Biaya Trasportasi, dan Biaya Kantor Didapat Probabilitas $=95,91 \%=$ $\mathrm{Z}=1,739 \mathrm{Td}=107,713$ hari $\approx 108$ hari.Konsultan Pengawasan Jalan Dan Jembatan : Dari Hasil Jalur Keritis diambil: Tenaga Teknik, Biaya Trasportasi, dan Biaya Kantor Didapat Probabilitas $=93,94$ $\%=\mathrm{Z}=1,556 \mathrm{Td}=140,535$ hari $\approx 141$ hari.Konsultan Pengawasan Gedung Kantor : Dari Hasil Jalur Keritis diambil: Tenaga Teknik, Biaya Trasportasi, dan Biaya Kantor Didapat Probabilitas $=99,99 \%=\mathrm{Z}$ $=3,503 \mathrm{Td}=299,194$ hari $\approx 299$ hari

\section{KESIMPULAN DAN SARAN}

\section{Kesimpulan}

Penelitian ini membahas tentang dilakukan pada proyek konstruksi yang dilaksanakan di bidang PSDA, bidang Bina Marga dan bidang Cipta Karya di lingkungan Dinas Pekerjaan Umum dan Tata Ruang Pemerintah Kota Tarakan, Provinsi Kalimantan Utara. Berdasarkan hasil analisis data dan pembahasan yang telah dilakukan, maka disimpulkan :

Dalam mencari lintasan kritis dengan menggunakan metode PERT-CPM mempunyai beberapa langkah yaitu pertama membuat table rencana kegiatan, kedua membuat network planning, ketiga menghitung pekerjaan maju dan mundur dan yang paling akhir adalah menghitung kelonggaran waktu. Lintasa kritis yang diperoleh adalah yaitu Pembanguan dan Pegawasan Saluran Drainase : Dari perhitungan dengan mengunakan metode 
PERT-CPM dapatlah 99,83 \% waktu optimal 91 hari kalender dan 13 minggu,lebih cepat dari kontrak 120 hari kalender 14 minggu dan konsultan pengawasan 95,91\% waktu optimal yang didapat yaitu 104 hari kalender ini sudah termasuk dengan lapora keowner ( pemilik Proyek ).

- Pembanguan dan PegawasanJalan dan Jembatan : Dari perhitungan dengan mengunakan metode PERT-CPM dapatlah $98,61 \%$ waktu optimal 118 hari kalender dan 17 minggu,lebih cepat dari kontrak 150 hari kalender 20 minggu dan konsultan pengawasan 93,94\% waktu optimal yang didapat yaitu 134 hari kalender ini sudah termasuk dengan lapora keowner (pemilik Proyek).

- Pembanguan dan Pengawasan Gedung Kantor : Dari perhitungan dengan mengunakan metode PERT-CPM dapatlah $99,98 \%$ waktu optimal 280 hari kalender dan 37 minggu,lebih cepat dari kontrak 360 hari kalender 48 minggu dan konsultan pengawasan 99,99\% waktu optimal yang didapat yaitu 300 hari kalender ini sudah termasuk dengan lapora keowner (pemilik Proyek).

\section{Saran}

Berdasarkan hasil penelitian dan analisis yang dilakukan, serta kesimpulan di atas, maka beberapa saran adalah:

- Dengan hasil penelitian ini disarankan kontraktor dan Konsultan harus memiliki Tenaga Ahli dibidang Menajemen Proyek jadi dapat mehitung jadwal kerja yang diberikan oleh Owner (pemilik Proyek), untuk kegiatan berjalan dengan lancar sesuai penjadwalan proyek sehingga dapat lebih menghemat waktu.

- Dari hasil penelitian ini disarakan Dinas Pekerjaan Umum dan Tata Ruang untuk mempertimbangan waktu yang diberikan dan konsultan pengawasan ada standarsasi yang dikeluarkan oleh pemerintah.

- Proyek - proyek Pemerintah atau swasta pasti behubungan dengan network planning atau lintasan kritis maka keterlambatan dapat diketahui kontraktor dan pengawasan dilapangan dengan cepat. Bagi Peneliti ini mempunyai keterbatasan dalam data data secara lengkap sehingga perlu dianalisa lebih lanjut berdasarkan program yang lain metode. Selain PERT dan CPM.

\section{DAFTAR PUSTAKA}

Ervianto, I. W, 2005. Manajemen Proyek Konstruksi(edisi revisi). Yogyakarta : Cv. Andi Offset.

Heizer, Jay dan Barry Render. 2005. Operations Management: Manajemen Operasi. Jakarta : Salemba Empat.

Lock,Dennis. 1990. Manajemen Proyek (edisi 5). Jakarta : Erlangga.

Maharany,Fajarwati. 2006. Analisis Optimasi Percepatan Durasi Proyek dengan Metode Least Cost Analysis. Utilitas, Vol.14, No.1, h.113-130.

Nugraha,Paulus, 1985, 1986. Manajemen Proyek Konstruksi (edisi 1)/ (edisi 2). Surabaya : Kartika Yudha.

Sukanto. 2001. Manajemen Proyek (edisi 5). Yogyakarta : BPFE UGM.

Soeharto,1995. Manajemen Proyek: dari konseptual sampai operasional. Jakarta : Erlangga.

Aditya,T 2009. Perencanaan dan Penyelesaian Masalah Infrastruktur Perkotaan Melalui Integrasi SIG Kolaboratif dan SIG Partisipasi Publik. Fakultas Tekni UGM: teknik geodesi dan Geomatika.

Apriliasari,Asdita,Indrayani.Kriteria

Penilaian Konsultan Pengawas Proyek Konstruksi Milik Pemerintah. Surabaya : ITS.

Brian, McLoughlin. 1969. Urban dan Regional Planning: A Systems Approach. Feber : London. 